\title{
Географическое образование
}

УДК 911.375

DOI: https://doi.org/10.26456/2226-7719-2021-2-78-92

\section{КЕЙС ДЛЯ ГЕОГРАФОВ-МАГИСТРОВ: БАРСЕЛОНА}

\author{
Н.Д. Соколов
}

ФГБОУ ВО «Тверской государственный университет», г. Тверь

Предложена авторская разработка кейса для изучения городских агломераций в курсе «Пространственное планирование» - для магистровгеографов. Городские агломерации как основные формы современного городского пространства - это один из типов районов территориального планирования (районной планировки) во всех странах мира. В России для городских агломераций разрабатываются Схемы территориального планирования. В географии - это популярная тема исследований. Опыт профессиональной оценки трансформации планировочной структуры городских агломераций - важная компетенция географов-исследователей. Кейс разработан для Барселоны (Испания).

Ключевые слова: кейс-метод, саse-study, классификачия кейсов, городские агломерачии, Барселона, генеральный план, картографический анализ, планировочная структура агломерации, планировочные особенности: форма плана и форма планировки города, планировочные определители.

В современном географическом образовании метод-кейсов - один из разнообразных активных методов обучения [2]. Сущность метода кейсов - анализ конкретных ситуаций с высокой степенью проблемности и/или нестабильности, часто это реальный сюжет «в лицах» [5]. Примеры учебных кейсов, выполненных по общему алгоритму с критериями оценивания уровня сформированности профессиональных компетенции, см. в публикациях [1;3]. Классификационных признаков кейсов много, а варианты всегда можно дополнить. Кейс разработан для географовстудентов магистратуры ТвГУ по теме «Городские агломерации» в учебной дисциплине «Пространственное планирование». Планировочный кейс предложен для формирования профессионального умения (владения) оценки ключевого элемента пространственного развития крупных городов и городских агломераций - планировочной структуры (каркасных элементов, общей формы плана и формы планировки, узлов и пр.). При разработке кейса на примере Барселоны (Испания) были учтены основные классификационные признаки, в том числе потребовались дополнения по видам кейсов. В классификаторе кейсов указаны основные признаки и варианты (виды). Маркером 
выделены признаки как оценочные параметры разработанного кейса «Барселона».

1. Сферы применения (наш дополнительный вариант выделен жирным шрифтом):

$\square$ Бизнес-образование

$\square$ Социальная работа

$\square$ Научные исследования

$\square$ Художественная литература

$\square$ Образовательная практика

У Предпроектные разработки (территориальное планирование)

2. Виды анализа (в нашем случае - сочетание):

$\square$ Проблемный

$\square$ Системный

$\square$ Праксеологический

$\nabla \underline{\text { Прогностический }}$

3. Технологии, используемые при решении кейсов (в нашем случае - сочетание), наш дополнительный вариант выделен жирным шрифтом:

$\square$ игра

$\square$ «мозговой штурм»

$\square$ моделирование

$\square$ мысленный эксперимент

$\square$ дискуссия

$\square$ картографический анализ

4. Виды кейсов (по содержанию):

$\square$ Ситуационные задачи

$\square$ Инциденты

$\square$ Разбор деловой корреспонденции

$\square$ Ситуационные игры

5. Виды кейсов (по размеру анализируемого материала):

малые (1-5 страниц)

$\nabla$ большие (до 100 страниц)

6. Виды кейсов (по готовности/наличию необходимого аналитического материала):

$\checkmark$ с полным набором фактических данных;

$\square$ с избыточным набором фактических данных; 
с неполным набором фактических данных;

с избытком одних данных и недостатком других.

7. Формируемые умения:

идентификация проблем, возможностей;

$\square$ оценка ранее принятых решений,

$\square$ анализ проблем или результатов;

разработка критериев решения;

разработка и оценка альтернатив;

$\square$ ■ разработка плана действий и т.д.

Структура кейса (все элементы в нашем кейсе есть):

- Ситуация

- Контекст

- Комментарий

- Вопросы и задания

- Приложения (по теме «Городские агломерации»: лекция, текст в электронном учебнике, планировочные определители)

Самооценка разработанного кейса по признакам «хорошего кейса»:

$\checkmark$ Использование актуальной информации

$\square$ Направленность на эмпатию с действующими лицами

$\square$ Опора на реальные источники

च Отражение проблем понятных студентам

$\checkmark$ Решаемость в определенных временных рамках

$\checkmark$ Многовариантность решений

Кейс снабжён расширенным списком литературы, пояснениями, разновременными картами Барселоны и определителями: формы плана и формы планировки городов, районов, концепции развития агломераций, варианты расширения больших городов и агломераций (это рисунки, в этой статье они не приведены).

Кейс для магистров по дисциплине «Пространственное планирование. Тип районов планирования: городские агломерации»

Тема: Трансформация планировочной структуры Барселоны: концепции разных лет.

Описание проблемной ситуации: Барселона - столичная агломерация Испании решает вопрос расширения площади в связи со значительным экономическим ростом и ростом населения. 
Дискуссионным остаётся вопрос о концепции развития планировочной структуры агломерации.

\section{Пояснения:}

На протяжении многовековой истории Барселоны планировочная структура города претерпела ряд изменений. Первые планы стали появляться в XVIII веке. Далее город масштабно развивался.

Городская агломерация Барселоны - это географическая зона (территориальный объект), которая выходит за пределы административной зоны и впервые была определена законом 1968 года и

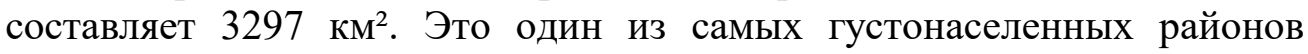
Европы. Барселона занимает стратегическое положение на юге Европы в центре Средиземноморского коридора, соединяющего Испанию с остальной частью континента. Это привилегированное место стало эпицентром каталонской территории. Данная территория включает сельскохозяйственные районы дельты Льобрегата, полностью урбанизированные районы Барселоны и большие зеленые зоны массивов Гарраф, Кольсерола и Сьерра-де-Марина.

\section{Вопросы кейса:}

1. Какой/какие критерии использованы при формировании Барселонской агломерации? Выбрать из 3-х (подчеркнуть): 1) транспортная доступность, рассчитывается по районам со сложившейся дорожной сетью; 2) расселение (повышенная концентрация населения вокруг Старого города); 3) экономический принцип: развертывание мест работы и обеспечение этих мест всеми необходимыми ресурсами.

2. Установить исходные планировочные особенности Барселоны (по первой - старой карте города).

3. Установить концепции и направления развития Барселоны в XVIII-XXI вв. Заполнить табл. Использовать два определителя: по 3.Е. Дзенису [5] и Е.Н. Перцику [7, 8]. Может ли быть использовано сочетание разных концепций для отдельных частей городской агломерации?

4. Когда Барселона стала ядром городской агломерации? Сколько ядер у современной агломерации?

5. Модель пространственного развития агломерации Барселона (оценка экспертов) [9, с. 11].

6. Самостоятельно выбрать концепцию и направление перспективного развития Барселоны названия модель см. в определителях). Обосновать свой выбор. Это соответствует действующему генеральному плану Барселоны? 
7. Определить параметры, по которым агломерация Барселона занимает лидирующие позиции среди 14 крупнейших городских агломераций мира [9, с. 9, 11, 21, 49, 56-57, 64, 70-76, 98, 159].

8. Перевесим на русский язык формулировку основного направления стратегии развития агломерации Барселоны [9, c. 140].

Пояснение: заполнить табл. (сравнение разновременных карт, которые и будут иллюстрировать динамику планировочной структуры). Если записывать свои рассуждения в эту таблицу - получатся ответы на все вопросы. По первой карте (1706 год) установить только планировочные особенности (форму плана и форму планировки). Концепции развития устанавливать методом визуального сравнения последовательных пар разновременных карт (генпланов).

табли ича Формирование планировочной структуры и расширение Барселоны

\begin{tabular}{|c|c|c|}
\hline 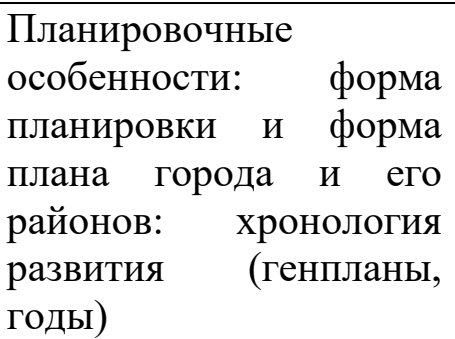 & $\begin{array}{l}\text { Концепции } \\
\text { планировочной } \\
\text { структуры } \\
\text { Перцику Е.Н.) }\end{array}$ & $\begin{array}{l}\text { Направления } \\
\text { развития (по } \\
\text { Дзенису)= модели } \\
\text { расширения } \\
\text { площади }\end{array}$ \\
\hline $\begin{array}{l}\mathbf{1 7 0 6} \text { год. } \\
\text { Барселоны } \\
\text { Вишера. }\end{array}$ & $\begin{array}{l}\text { Исходныле } \\
\text { планировочные } \\
\text { особенности: } \\
\text { веерная планировка } \\
\text { улиц, компактная } \\
\text { форма города-порта } \\
\text { (рис. 1) }\end{array}$ & - \\
\hline $\begin{array}{l}\text { Карта Барселоны } 1801 \\
\text { года с изображением } \\
\text { города и планом } 1740 \\
\text { года. }\end{array}$ & & \\
\hline $\begin{array}{lr}\mathbf{1 8 5 5} \text { год. } & \text { План } \\
\text { Барселоны } \\
\text { пригородов. }\end{array}$ & & \\
\hline $\begin{array}{lll}1860 & \text { год. } & \text { План } \\
\text { Идефонса Серда. } & \\
\end{array}$ & & \\
\hline $\begin{array}{lcr}\mathbf{1 8 8 8} & \text { год. } & \text { План } \\
\text { Всемирной } & \text { Выставки в }\end{array}$ & & \\
\hline
\end{tabular}




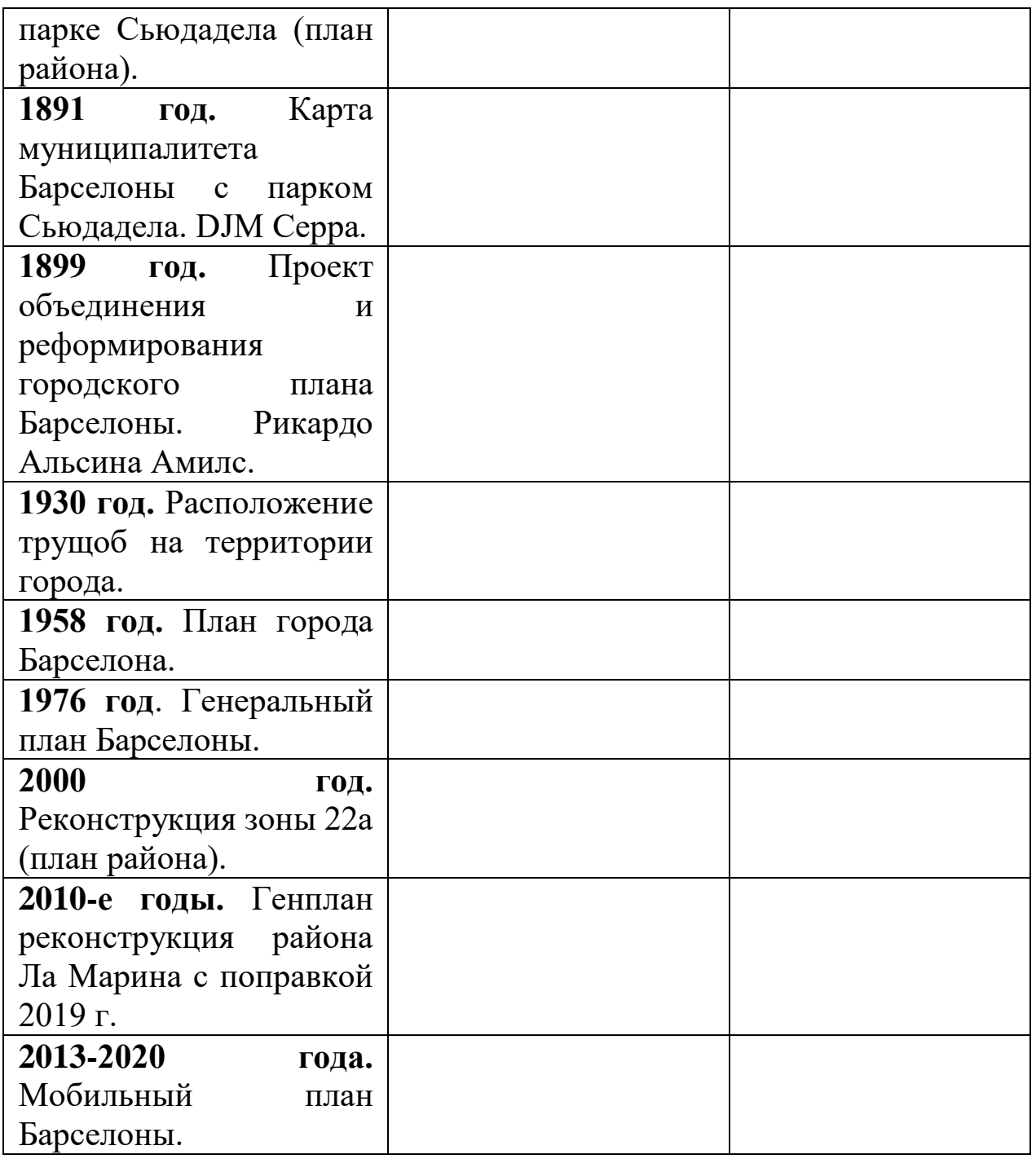

Bbl6od:

\section{Материалы и пояснения для ответа:}

- Исходные материалы (карты) и статьи в журналах (см. список). 


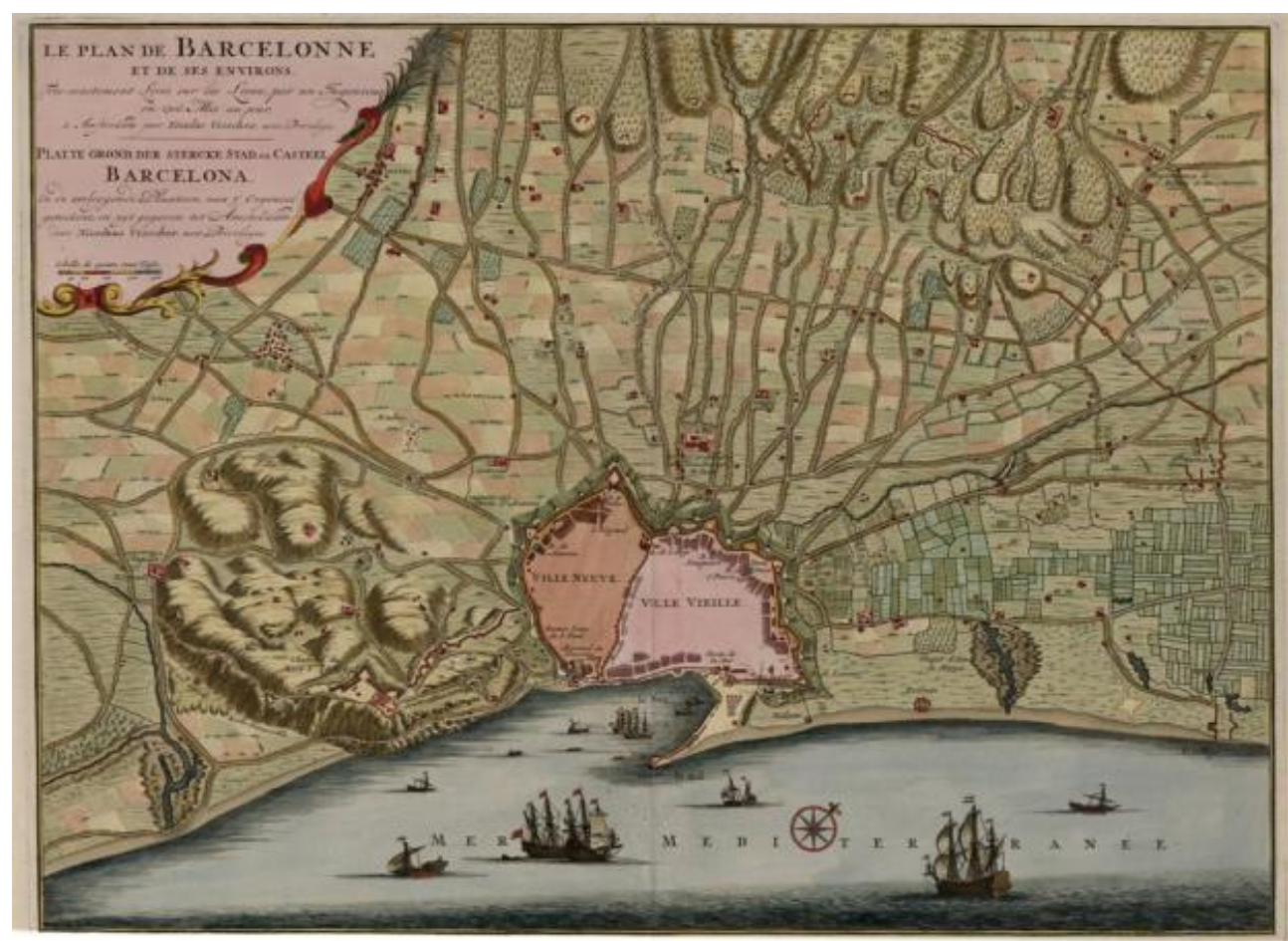

Р и с. 1. Карта Барселоны 1706 года. Николас Вишер. Источник [11]

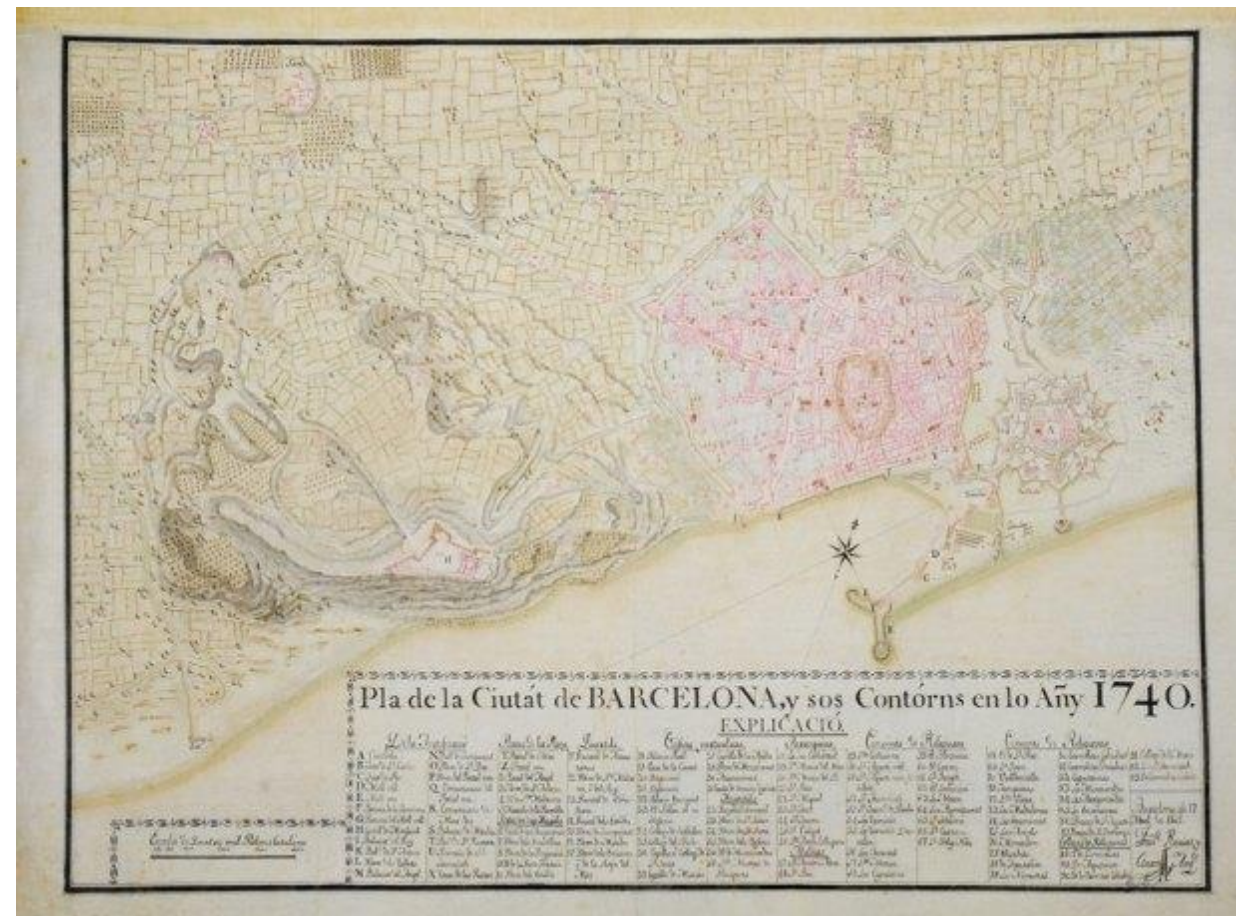

Р и с. 2. Карта Барселоны 1801 года с изображением города и планом 1740 года. Источник [11] 


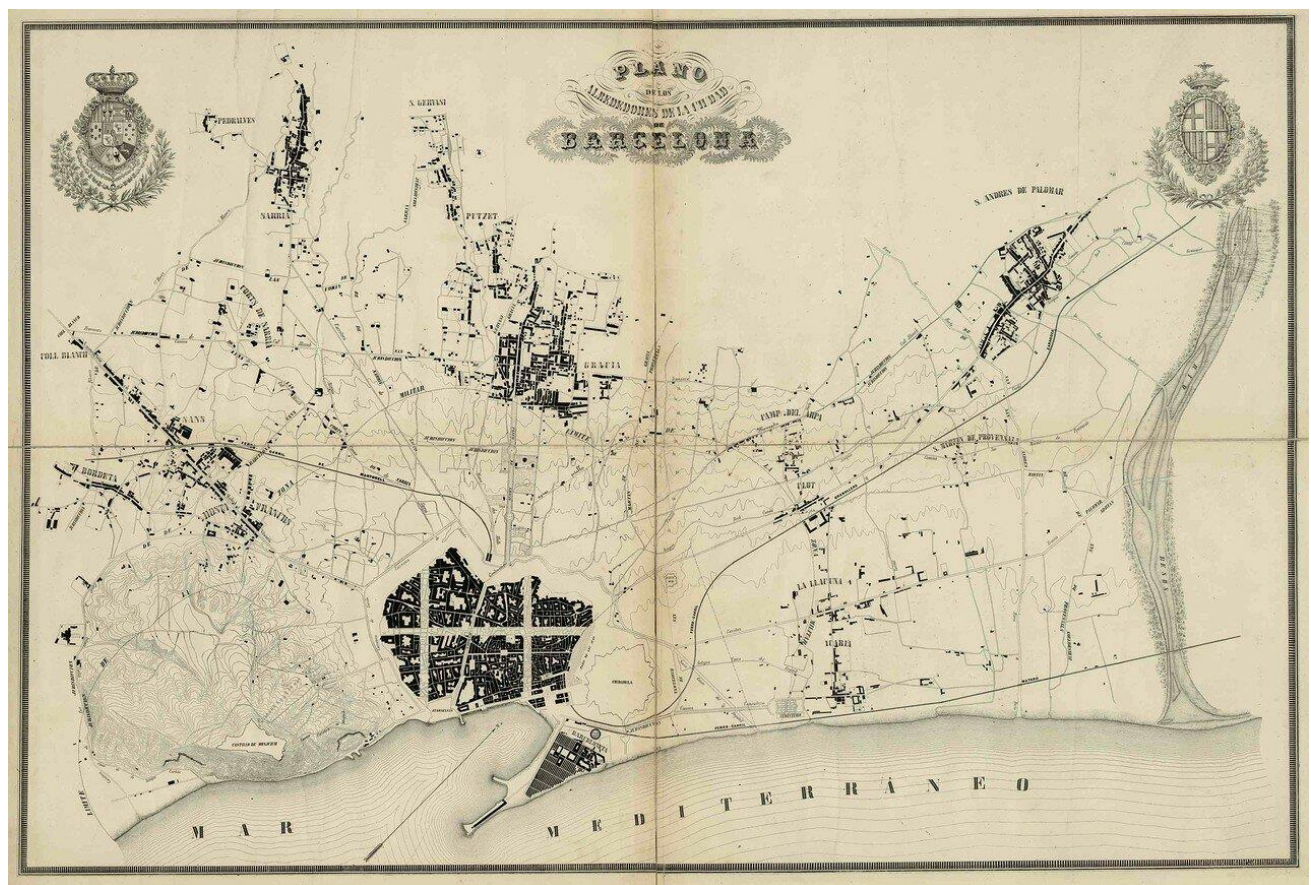

Р и с. 3. 1855 год. План Барселоны и пригородов. Источник [11]

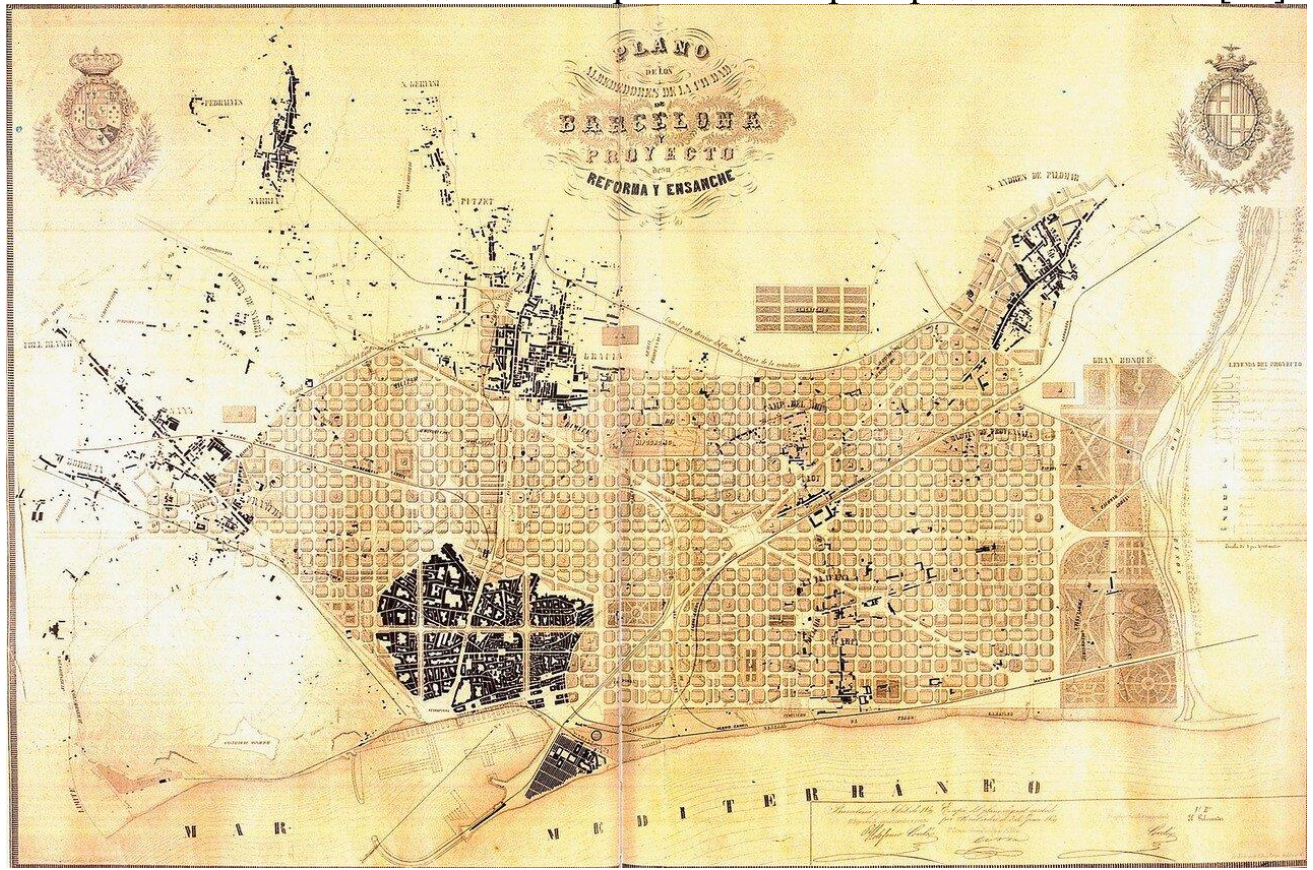

Р и с. 4. 1860 год. План Идефонса Серда. Источник [4] 


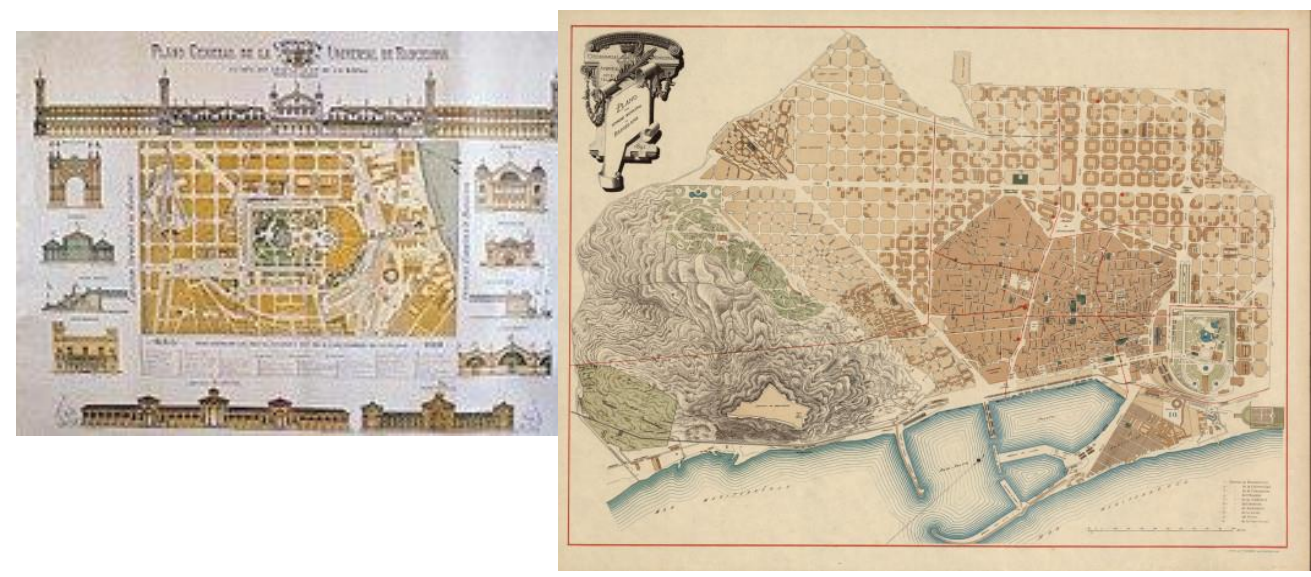

Р и с. 5. План Всемирной Выставки 1888 года. Источник [13]
Р и с. 6. Карта муниципалитета Барселоны. DJM Ceppa, 1891 г. Источник [11]

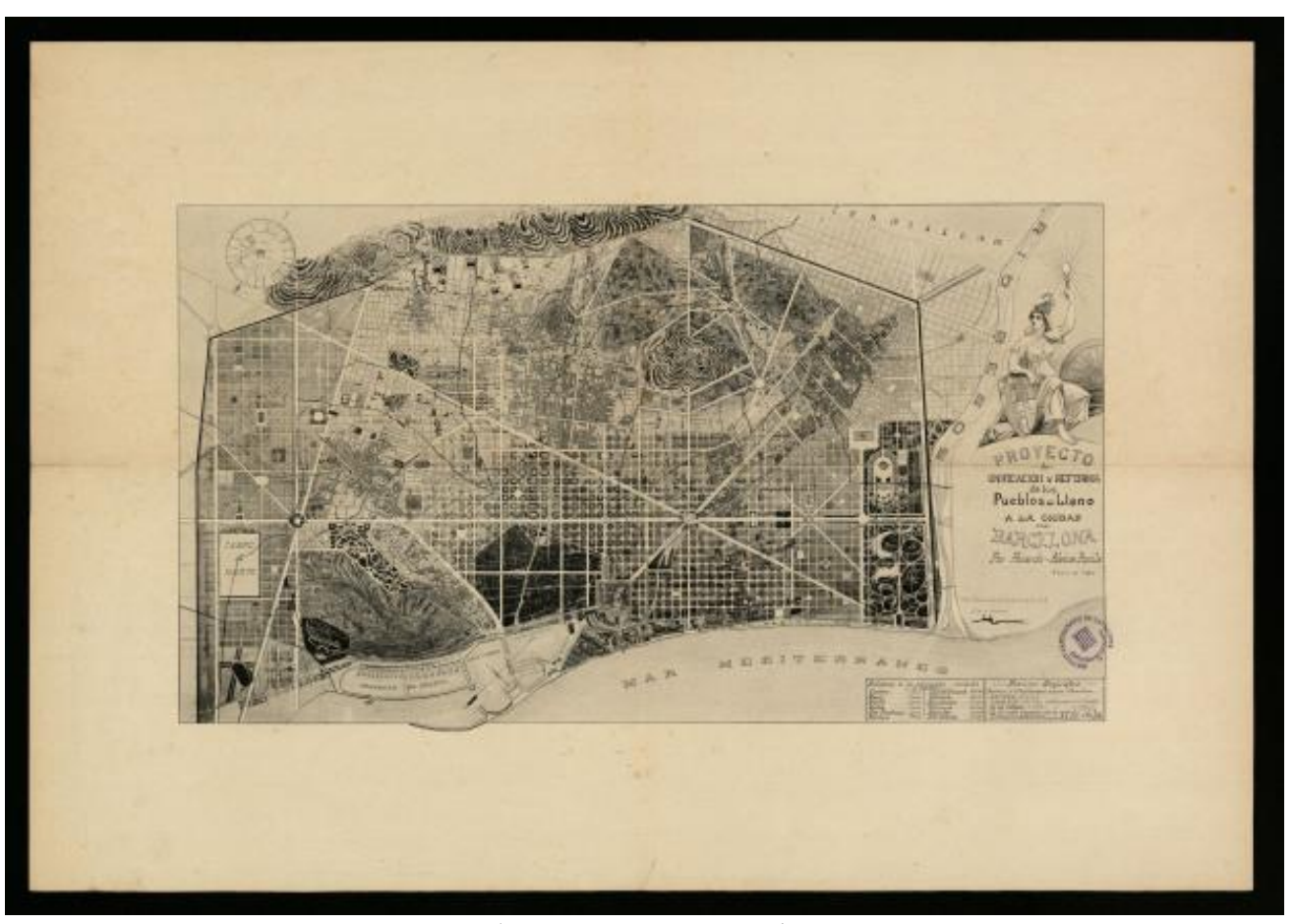

Р и с. 7. Проект объединения и реформирования городского плана Барселоны. Рикардо Альсина Амилс, 1899 г. Источник [11] 


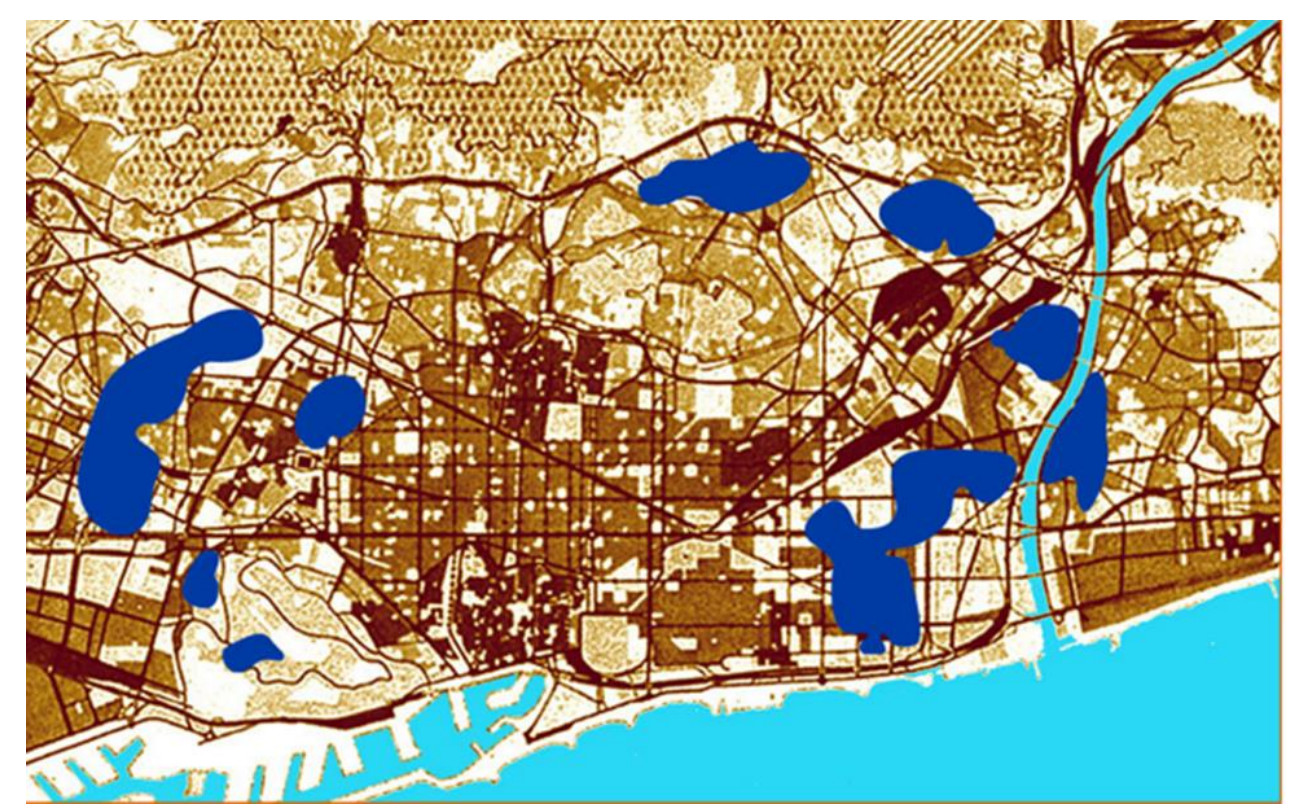

Р и с. 8. Расположение трущоб в Барселоне, 1930 г. Источник [15]

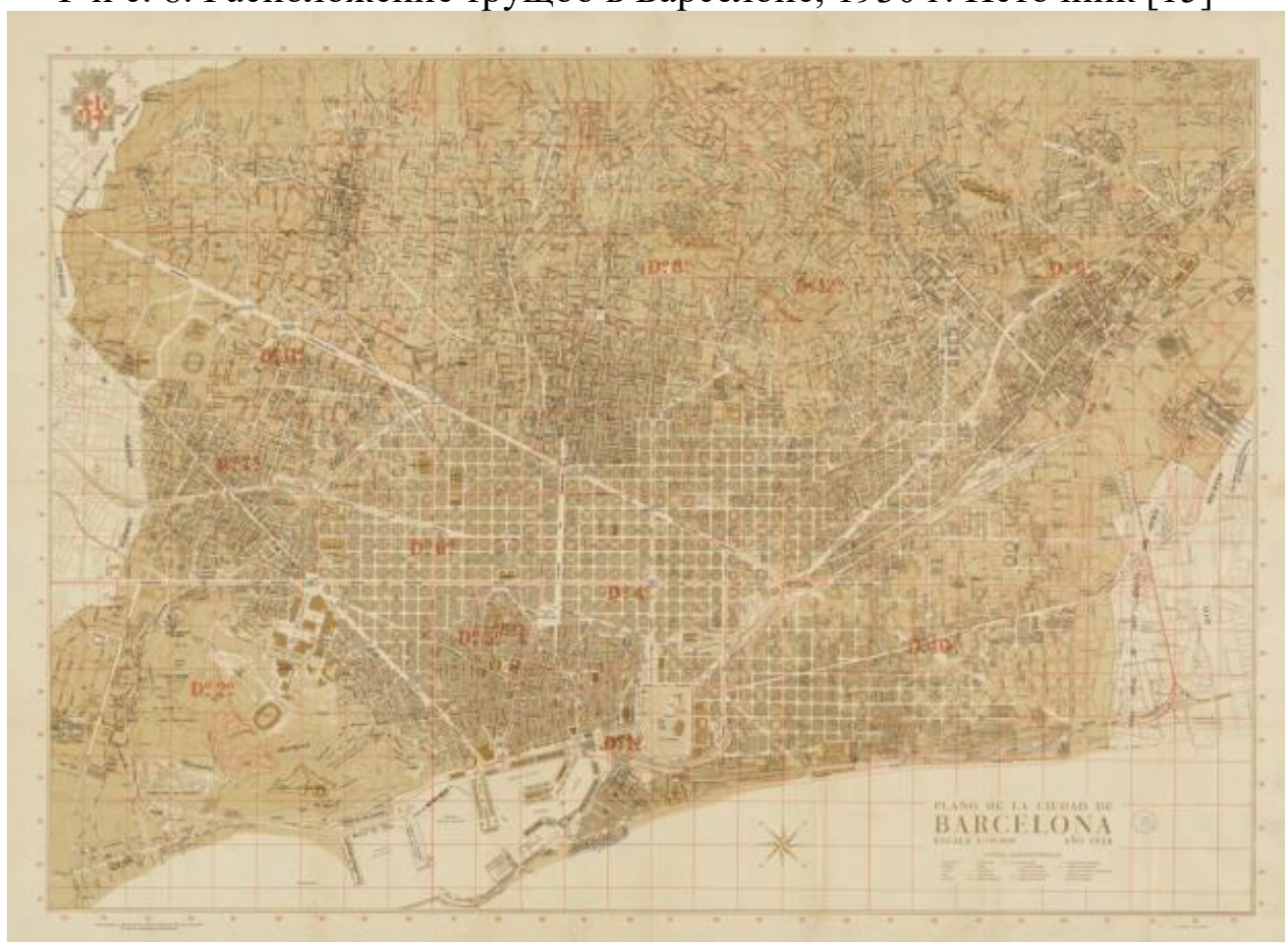

Р и с. 9. План города Барселона, 1958 г. Источник [11] 


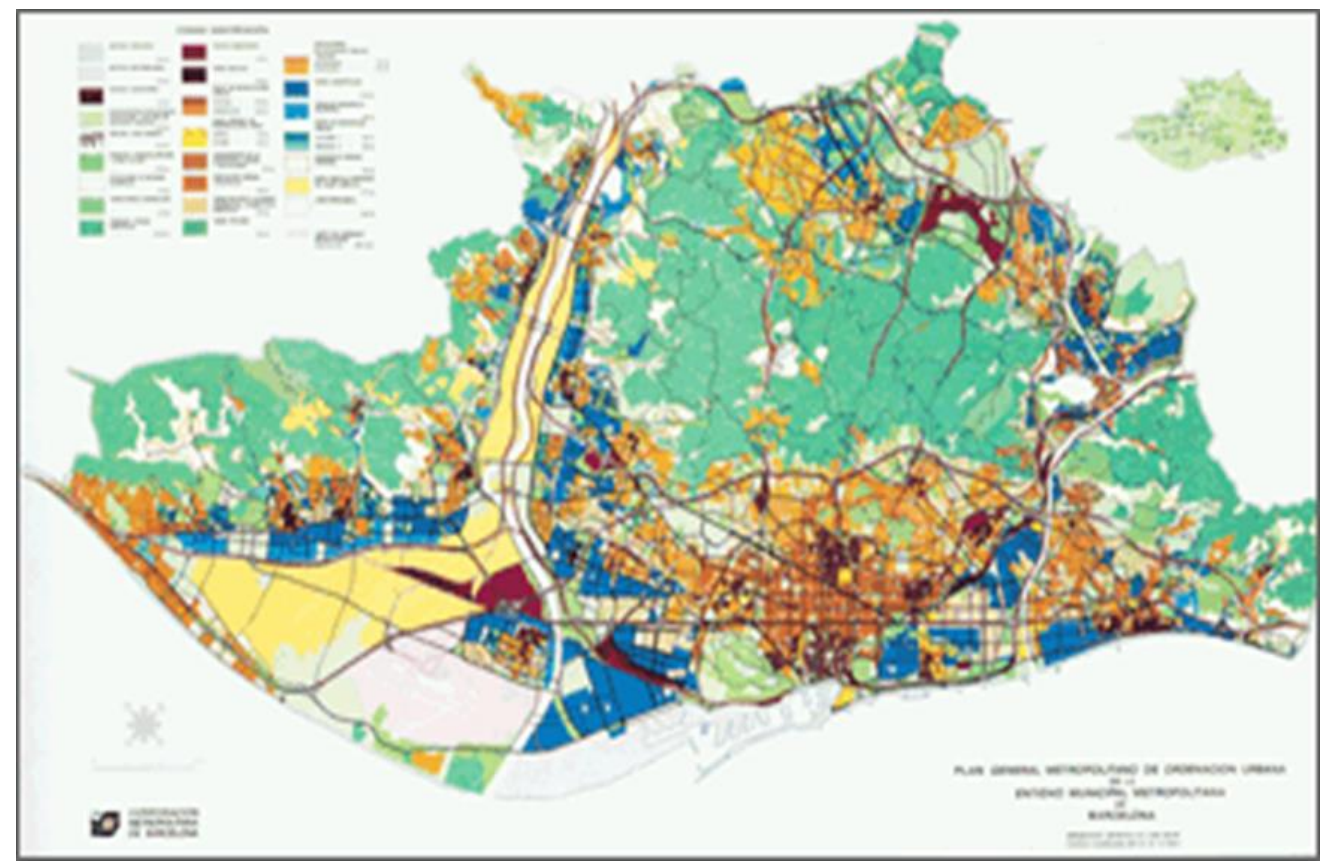

Р и с. 10. Генеральный план Барселоны, 1976. Источник [14]
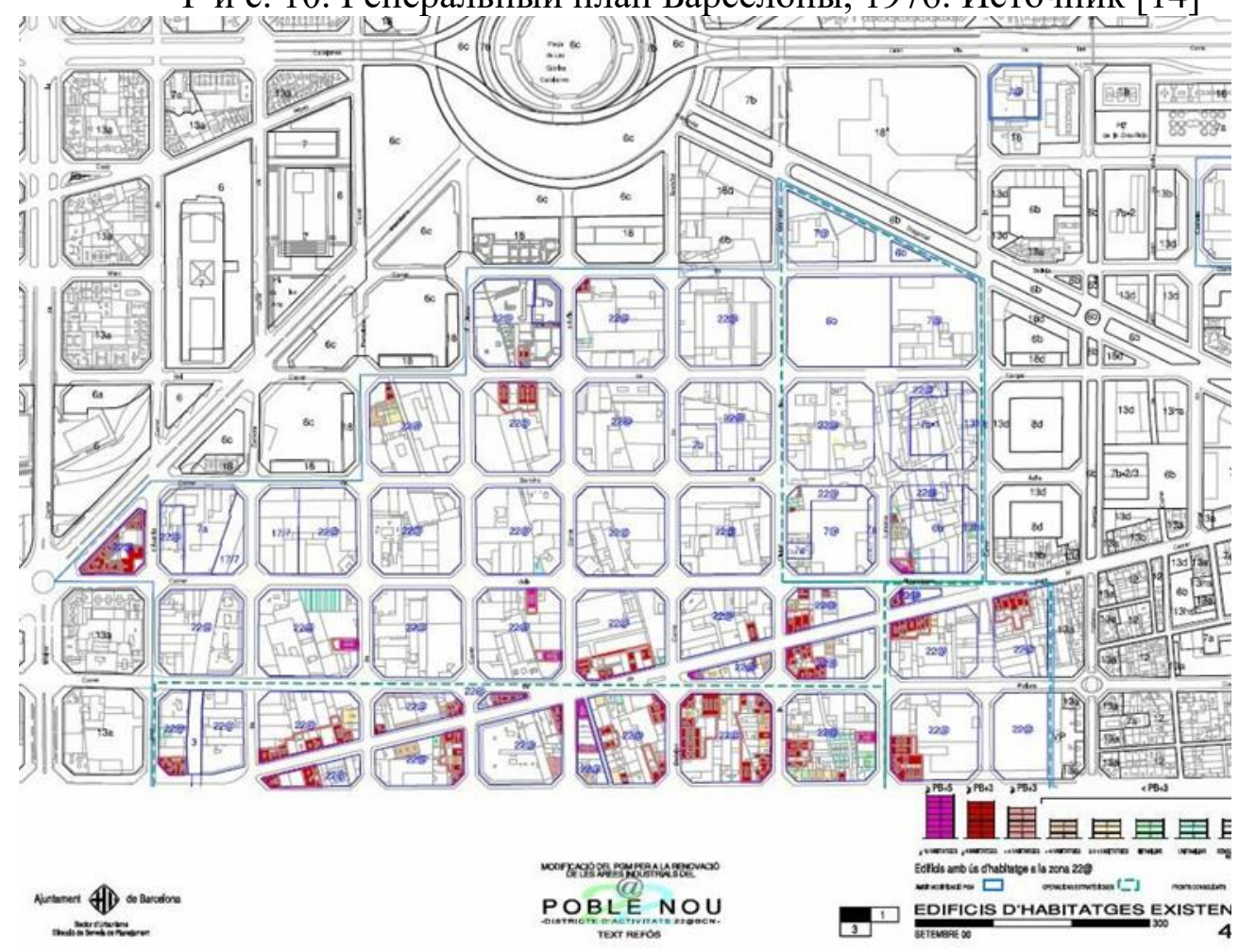

Р и с. 11. Реконструкция зоны 22а (план района), 2000. Источник [10] 


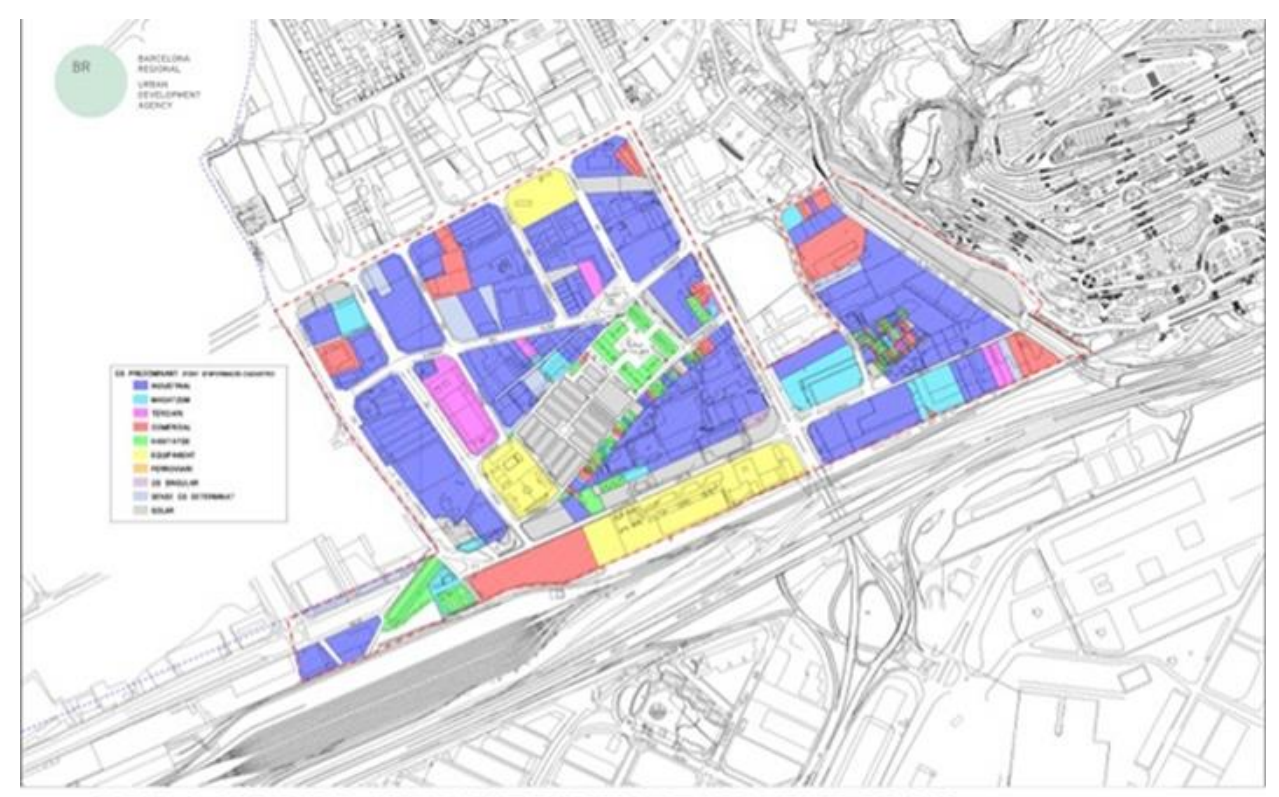

PEI LA MARINA. INFRASTRUCTURE MASTER PLAN

-75 ha.

-11.000 housing units

- $1.1 \mathrm{M}$ sqm. (75\% residential, $25 \%$ activity)

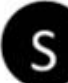

Р и с. 12. 2010-е годы. Генплан реконструкция района Ла Марина с поправкой 2019 г. Источник [10]

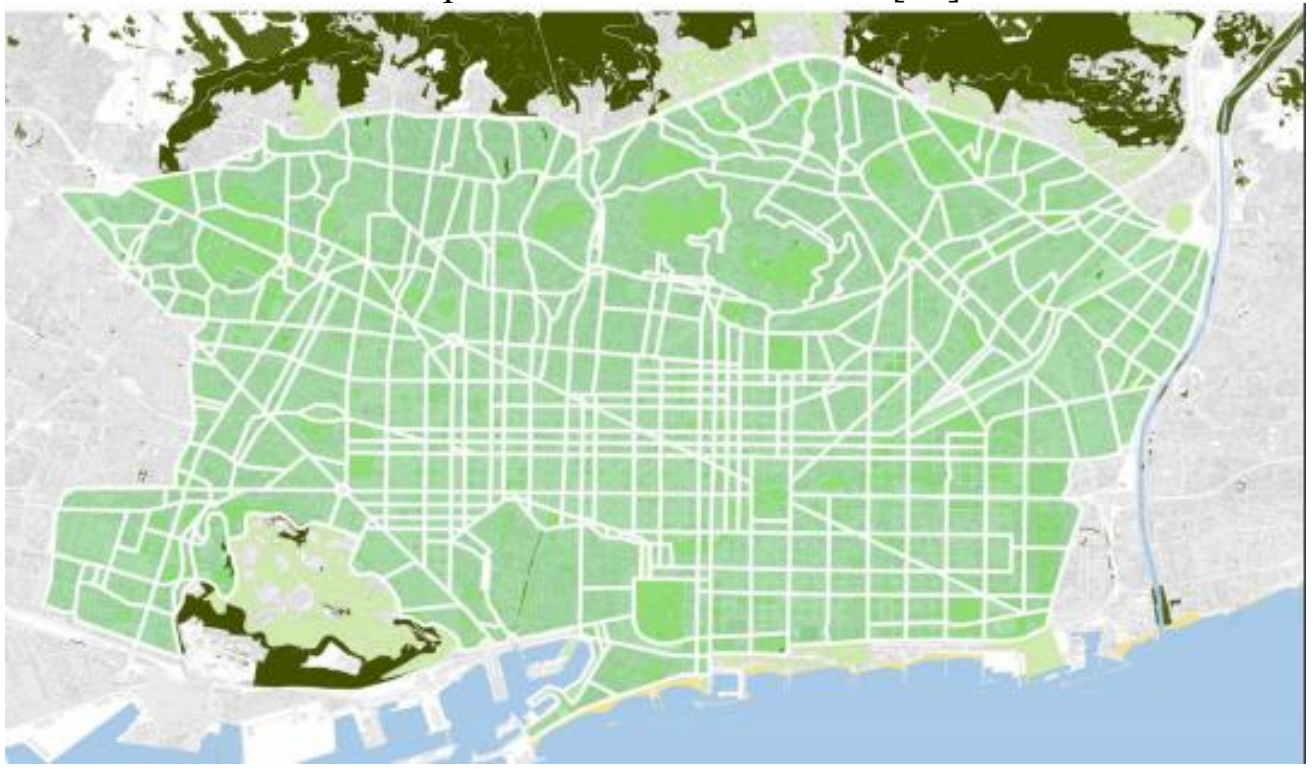

Р и с. 13. Барселона: план мобильности на 2013-2020 гг. На карте показана сеть транспортных коммуникаций. Источник [12]

Для дифференцированной и объективной оценки результатов выполненного кейса необходимо разработать критерии. Наш вариант: 
Критерии оценки выполненного кейса Барселона

(максимальная оценка $\mathbf{3 0}$ баллов), подчёркнуты элементы задания, вызвавшие наибольшие затруднения при ответах:

2. Умение анализировать разновременные карты с использованием определителя

- $\quad$ точное определение - 5 баллов

- делает ошибки - снимаем по 1 баллу

3. Умение составлять краткую характеристику планировочной структуры агломерации (описание):

- краткая точная характеристика - 5 баллов

- дана точная характеристика, но описание требует стилистической редакции - снимаем 2 балла

- неверный ответ - 0 баллов.

4. Умение выявлять изменения планировочной структуры агломерации, в том числе кардинальные изменения (трансформацию):

- Точно выявляет изменения методом анализа разновременных карт - 5 баллов

- Называет изменения, которые сформулированы в источниках (цитирует) - 3 балла

- Не выявляет и не описывает трансформацию - 0 баллов

5. Умение определять (устанавливать) формы трансформации планировочной структуры агломерации:

- Делает вывод о преемственности развития агломерации по концепции поясного зонирования с веерным фронтальным расширением агломерации на юго-восток -5 баллов

- Знает основные формы трансформации и точно устанавливает доминирующую форму или сочетание, точно указывает даты этих изменений - 5 баллов

- Признаёт факты изменений, но не называет формы трансформации планировочной структуры агломерации (и даты) - 3 балла

- Не может сформулировать изменения, не называет формы трансформации.

6. Умение моделировать варианты перспективной планировочной структуры агломерации, рекомендовать концепцию развития и направление/направления пространственного развития агломерации:

- Точно указывает адекватную концепцию развития агломерации и направления пространственного развития (модели), аргументирует свой выбор - 5 баллов 
- Указывает основную концепцию развития агломерации и направления пространственного развития (модели), не аргументирует свой выбор - 3 баллов

- Затрудняется определить концепцию и модель расширения агломерации - 0 баллов.

Методический вывод для усиления подготовительной теоретической работы со студентами: добавить в тексты лекций формы трансформации, так как варианты переходов от одной модели к другой все понимают и видят на картах, но найти специальные оценочные понятия для описания изменений не смогли. Это классические формы пространственной трансформации: расширение, сжатие, дробление, ликвидация, создание нового. Стоит добавить пояснения к каждой карте задания, иногда уточнить условные знаки, назвать даты создания ключевых объектов и др.

Кейс позволил оценить степень усвоения важной компетенции географа-исследователя: опыт экспертной оценки и моделирования городских агломераций - объектов географического исследования и территориального планирования. Разработка и использование метода кейсов в подготовке географов-исследователей - актуальная задача методики преподавания географии в высшей школе.

\section{Список литературы}

1. Альсулейман М.И. Кейс для географов-магистров: Большой Дамаск // Вестн. Твер. гос. ун-та. Сер. «География и геоэкология». 2020. Выпуск 2 (30). C.90-103. URL: http://eprints.tversu.ru/9624/1/Vestnik_Geograf_2_30_2020-90103.pdf.

2. Альсулейман М.И., Яковлева С.И. Активные методы обучения в высшей школе// Вестн. Твер. гос. ун-та. Сер. «География и геоэкология». 2019. Выпуск 4 (28). C.73-83. URL: https://elibrary.ru/item.asp?id=41506077.

3. Вострова М.В. Кейс для географов-магистров: исторические поселения как объекты географии и территориального планирования // Вестн. Твер. гос. ун-та. Сер. «География и геоэкология». 2020. Выпуск 4 (32). C.47-59. DOI: https://doi.org/10.26456/2226-7719-2020-4-47-59.

4. Генеральный план Барселоны 1859 года. URL: https://giper.livejournal.com/148151.html.

5. Дзенис 3.Е. Методология и методика социальноэкономгеографических исследований. Рига, 1980.

6. Кейсы в преподавании гуманитарно-социальных дисциплин: учебно-метод. пособие / под ред. руководителя методической 
школы по андрагогике ИнНО, канд. ист. наук, доц. О.Н. Хохловой, - Тверь: Твер. гос. ун-т, 2012. - 64 с. URL: http://hohlova.tversu.ru/images/stories/material/keise.pdf.

7. Перцик Е.Н. Районная планировка (географические аспекты). М., 1973.

8. Перцик Е.Н. Районная планировка (территориальное планирование): Учеб. пособие для студ. М., 2006.

9. Пространство города для человека. Исследование уровня и динамики градостроительного развития крупнейших мегаполисов мира // PwC, июнь 2018. - 218 с. [Электронный ресурс]. Режим доступа: https://www.pwc.ru/ru/publications/city-space/smart-citfull.pdf.

10. Чирков A (2012). Как строят Барселону. URL: https://archplatforma.ru/?act=1\&nwid=2051.

11. Catastrophic cartographic. Barcelona. URL: https://cartografic.wordpress.com/2011/10/10/barcelona-4-2/.

12. Estratègia de mobilitat turística de Barcelona (2017). URL: https://ajuntament.barcelona.cat/turisme/sites/default/files/memoria_e mt_20171204_1.pdf.

13. Exposición Universal de 1888: la proyección de Barcelona como sede de eventos internacionales (2020). URL: https://redhistoria.com/exposicion-universal-de-1888-la-proyeccionde-barcelona-como-sede-de-eventos-internacionales/.

14. Spain.

URL: https://www.mlit.go.jp/kokudokeikaku/international/spw/general/spai n/index_e.html.

15. Waker A., Porraz B (2003). The case of Barcelona, Spain. URL: https://www.ucl.ac.uk/dpu-

projects/Global_Report/pdfs/Barcelona.pdf.

\section{CASE-STUDY FOR GEOGRAPHY RESEARCHERS: BARCELONA}

\section{N.D. Sokolov}

Tver State University, Tver

The author developed a case study for the study of urban agglomerations in the course "Spatial Planning" for geographers. City agglomerations as the main forms of modern urban space - this is one of the types of areas of territorial planning (district planning) in all countries of the world. In Russia, for urban agglomeration, Territorial planning schemes are being developed. In geography, this is a popular research topic. The experience of professional assessment of the transformation of the planning 
structure of urban agglomerations is an important competence of geography researchers. The case was developed for Greater Damascus (Syria).

Keywords : case-study method, case-study, case classification, agglomeration, Barcelona, master plan, cartographic analysis, planning structure of the agglomeration, the form of the plan and the layout of the city, planning specifier.

Об авторе:

СОКОЛОВ Никита Дмитриевич - выпускник бакалавриата кафедры туризма и природопользования ТвГУ (2020), студент 1 курса магистратуры по направлению «География», кафедра социальноэкономической географии и территориального планирования ТвГУ, e-mail: nikita.sok1998@mail.ru. Научный руководитель: д.э.н., профессор С.И. Яковлева. 